\title{
Removal of Salmonella Typhimurium Biofilm from Food Contact Surfaces Using Quercus infectoria Gall Extract in Combination with a Surfactant
}

\author{
Peetitas Damrongsaktrakul', Songsirin Ruengvisesh ${ }^{1 *}$, Arewan Rahothan ${ }^{1}$, \\ Nuttamon Sukhumrat ${ }^{1}$, Pravate Tuitemwong ${ }^{2}$, and Isaratat Phung-on ${ }^{3}$ \\ 'Department of Microbiology, Faculty of Science, King Mongkut's University of Technology Thonburi (KMUTT), \\ Bangkok 10140, Thailand \\ ${ }^{2}$ Food Safety Center, Institute for Scientific and Technological Research and Services (ISTRS), KMUTT, Bangkok \\ 10140, Thailand \\ ${ }^{3}$ Maintenance Technology Center, ISTRS, KMUTT, Bangkok 10140, Thailand
}

\begin{abstract}
Quercus infectoria (nutgall) has been reported to possess antimicrobial activities against a wide range of pathogens. Nevertheless, the biofilm removal effect of nutgall extract has not been widely investigated. In this study, we therefore evaluated the effect of nutgall extract in combination with cetrimonium bromide (CTAB) against preformed biofilm of Salmonella Typhimurium on polypropylene (PP) and stainless steel (SS) coupons in comparison with other sanitizers. The minimum inhibitory concentration (MIC) and the minimum bactericidal concentration (MBC) of nutgall extract and surfactants (CTAB and sodium dodecyl sulfate; SDS) were assessed. CTAB showed a more efficient antimicrobial activity than SDS and was selected to use in combination with nutgall extract for removing biofilm. To determine the biofilm removal efficacy, the PP and SS coupons were individually submerged in $2 x \mathrm{MBC}$ of nutgall extract $(256 \mathrm{mg} / \mathrm{ml})+2 \times \mathrm{MBC}$ of CTAB $(2.5 \mathrm{mg} / \mathrm{ml})$, nutgall extract alone $(256 \mathrm{mg} / \mathrm{ml})$, CTAB alone $(2.5 \mathrm{mg} / \mathrm{ml})$, distilled water, and $100 \mathrm{ppm}$ sodium hypochlorite for 5,15 , and $30 \mathrm{~min}$. The remaining sessile cells in biofilm were determined. Overall, the greatest biofilm removal efficacy was observed with nutgall extract + CTAB; the biofilm removal efficacy of sanitizers tended to increase with the exposure time. The SEM analysis demonstrated that S. Typhimurium biofilm on PP and SS coupons after exposure to nutgall extract + CTAB for $\mathbf{3 0}$ min displayed morphological alterations with wrinkles. This study suggests nutgall extract + CTAB may be an alternative to commonly used sanitizers to remove biofilm from food contact surfaces in the food industry and household.
\end{abstract}

Keywords: Quercus infectoria gall extract, Salmonella Typhimurium, biofilm removal, food contact surfaces, surfactants

Received: January 13, 2021 Accepted: January 31,2021

First published online: February 01, 2021

*Corresponding author Phone: +662470-8884 Fax: +662470-8891 Email: songsirin@gmail.com

pISSN 1017-7825 eISSN 1738-8872

Copyright(C) 2021 by The Korean Society for Microbiology and Biotechnology

\section{Introduction}

Foodborne diseases are a significant public health concern and also an impediment to social development globally [1]. Salmonella spp. have been one of the four key causative agents of foodborne diseases worldwide [2]. According to the U.S. Centers for Disease Control and Prevention (CDC), Salmonella spp. cause approximately 1.35 million foodborne infections, 26,500 hospitalizations, and 420 fatalities annually [3]. In Europe, the European Food Safety Authority and European Center for Disease Prevention and Control (EFSA and ECDC) reported 91,662 confirmed human salmonellosis cases in 2017; S. Enteritidis and S. Typhimurium were the top two serovars associated with the illnesses. The highest risk agent/food pairs were reported to be Salmonella in eggs and Salmonella in meat and meat products [4]. In Thailand, the Thailand Bureau of Epidemiology, Department of Disease Control, Ministry of Public Health reported 109,491 cases of foodborne illnesses in 2019, with Salmonella spp. as one of the major known pathogens causing the diseases [5].

Salmonella spp. are facultatively anaerobic, rod-shaped, non-sporeforming, Gram-negative bacteria belonging to the family Enterobacteriaceae [6]. Salmonella spp. can form biofilms, which are complex microbial communities embedded in an extracellular matrix or exopolymeric substances, including polysaccharides, proteins, and nucleic acids [7]. In the food industry, biofilms are undesirable since they serve as a habitat for 
pathogenic or spoilage microorganisms and can result in cross-contamination from food contact surfaces to food products $[8,9]$. Compared to planktonic cells, biofilms are 2 to $>3,000$ times more resistant to antimicrobial agents [10]. Therefore, biofilms cannot be effectively inactivated by commonly used sanitizers such as chlorine, peracetic acid, hydrogen peroxide, trisodium phosphate, and quaternary ammonium [9-14]. It has been reported that Salmonella spp. can be isolated from food contact surfaces in food processing facilities and domestic kitchens even after cleaning or disinfection $[15,16]$. The common food contact surfaces in food processing plants where microbial biofilms exist include filling or packaging equipment, floor drains, walls, cooling pipes, conveyors, collators, racks, hand tools, gloves, and freezers $[16,17]$. The presence of Salmonella spp. in the food processing areas suggests inefficient cleaning/sanitizing practices, which could increase the contamination level in the food processing facilities, resulting in salmonellosis outbreaks [7].

Quercus infectoria (nutgall) is a small tree indigenous to Greece, Asia Minor, Syria and Iran [18]. Upon attack by an insect (Diplolepis gallae tinctoriae or Cynips quercufolii), galls are formed on young branches on the tree [19]. The galls, also known as nutgalls or oakgalls, are the tree excrescences [20] that contain a mixture of tannin (60$70 \%$ ), gallic acid, methyl gallate, ellagic acid, and polyphenols. Previous studies have reported that nutgalls possess broad-spectrum anti-inflammatory, antivenom, antidiabetic, antioxidant, and antitumor activities [21]. Also, nutgalls have been shown to possess antimicrobial activities against pathogens (e.g. S. enterica, Shigella flexneri, Helicobacter pylori, Streptococcus mutans, Staphylococcus aureus, S. pyogenes, and Listeria monocytogenes) [20, 2226]. Many studies have been done to evaluate the antimicrobial activities and pharmaceutical properties of nutgall extracts $[18,24,26-28]$. However, research on the effect of nutgall extract in removing biofilm from food contact surfaces is limited.

In the food industry, some of the commonly used sanitizers and disinfectants (e.g., peroxide and peroxy acid mixtures, chlorine, carboxylic acids, acid anionic, and iodine compounds) may form toxic by-products (e.g., haloacetic acids, trihalomethanes, and other carcinogenic compounds) [29]. Conventional sanitizers and disinfectants may also contribute to antimicrobial resistance [29-32]. Therefore, the plant-derived extract would be a promising natural alternative for developing sanitizing agents. In this study, the effect of nutgall extract in combination with a surfactant (cetrimonium bromide; CTAB and sodium dodecyl sulfate; SDS) in removing preformed biofilm of $S$. Typhimurium on polypropylene (PP) and stainless steel (SS) coupons was assessed in comparison with other sanitizing agents. The morphological characteristics of biofilm before and after sanitizing treatments were also determined using a scanning electron microscope (SEM).

\section{Materials and Methods}

\section{Preparation of $Q$. infectoria Gall Crude Extract}

Nutgalls were washed with distilled water and then physically crushed using a mortar. The nutgall powder $(100 \mathrm{~g})$ was submerged in $95 \%$ ethanol $(500 \mathrm{ml})$ at room temperature for seven days. After filtration, the excess solvent was removed using a rotary evaporator (Model R-205, Canada) at $60^{\circ} \mathrm{C}$ until completely dry. [22].

\section{Preparation of Surfactant and Nutgall Extract Stock Solutions}

The stock solutions of CTAB (Ajax Finechem, Australia) and SDS (Ajax Finechem) were individually prepared by dissolving the surfactants in sterile distilled water to obtain the initial concentrations of 40 and $200 \mathrm{mg} / \mathrm{ml}$, respectively. To prepare the stock solution of nutgall extract, the crude extract was dissolved in $20 \%$ dimethylsulfoxide (DMSO; Fisher Scientific, UK) to achieve the initial concentration of $512 \mathrm{mg} / \mathrm{ml}$. The stock solutions were stirred using a magnetic stirrer until completely dissolved prior to use in a microbroth dilution assay.

\section{Determination of Total Phenolic Content}

The total phenolic content of the crude extract of nutgall was determined using a modified Folin-Ciocalteu colorimetric method as described by Dewanto et al. [33]. Briefly, $125 \mu$ lof the standard solution and $125 \mu$ of the nutgall extract were mixed in separate containers with $0.5 \mathrm{ml}$ of distilled water and $125 \mu \mathrm{l}$ of Folin-Cioceu reagent. After $6 \mathrm{~min}, 1.25 \mathrm{ml}$ of $7 \%$ sodium carbonate solution was added, followed by addition of water to the final volume of $3 \mathrm{ml}$. After a $90-$ min incubation, the samples were measured at $760 \mathrm{~nm}$ using a spectrophotometer (BioTek, USA) with the reference blank. The total phenolic content was expressed as milligrams of gallic acid equivalent in a gram of crude extract (mg GAE/g). Gallic acid was used as a standard.

\section{Preparation of $S$. Typhimurium Culture for Antimicrobial Assay}

S. Typhimurium ATCC13311 was maintained on slants of tryptic soy agar (TSA; HiMedia, India) at $4^{\circ} \mathrm{C}$. Morphology of the culture was confirmed on xylose lysine desoxycholate agar (XLD; HiMedia) and by microscopic observation. Working slants were prepared by transferring a loopful of $S$. Typhimurium to $10 \mathrm{ml}$ of tryptic soy broth (TSB; HiMedia). The culture was incubated at $37^{\circ} \mathrm{C}$ for $24 \mathrm{~h}$. After a 24 -h incubation, the culture was transferred to $10 \mathrm{ml}$ of TSB and incubated for $24 \mathrm{~h}$ prior to the assay.

\section{MIC and MBC Assays}

MIC values of the nutgall extract or surfactants were determined using the broth microdilution assay in a 96well plate. A volume of $100 \mu \mathrm{l}$ of the extract and surfactants were serially 10 -fold diluted in a 96 -well plate to obtain desired concentrations. Then, $100 \mu \mathrm{l}$ of $S$. Typhimurium in $2 \mathrm{x}$ TSB was added to the wells to achieve the concentration of approximately $5 \log \mathrm{CFU} / \mathrm{ml}$. Negative growth control containing the extract or surfactant in TSB without bacterium was included in the plates. Positive growth control bearing tested bacterium in TSB 
without antimicrobials was included. The plates were incubated at $37^{\circ} \mathrm{C}$ for $24 \mathrm{~h}$. After incubation, $30 \mu \mathrm{l}$ of $0.015 \%$ resazurin (Sigma Aldrich Co., USA) was added to the wells and the plate was incubated for $30 \mathrm{~min}$. After incubation, the plate was visually checked. Wells with a red color indicated bacterial growth. The lowest concentrations of the extract and the surfactants without bacterial growth (i.e., no red color) were deemed the MIC [34]. To study the bactericidal activity of the extract and surfactants, $100 \mu$ of the solution from microbial inhibitory wells was spread on TSA plates. Inoculated plates were incubated for $24 \mathrm{~h}$ at $37^{\circ} \mathrm{C}$. The concentrations of the extract and surfactants resulting in $\geq 3.0 \mathrm{log} \mathrm{CFU} / \mathrm{ml}$ reduction of tested microorganisms were regarded as bactericidal. The lowest concentrations of the extract and surfactants from three replicates were considered the MBC [35]. Three independent replicates of the study were completed; each replicate was performed in duplicate $(\mathrm{N}=6)$.

\section{Biofilm Formation on Polypropylene and Stainless Steel Coupons}

The PP (C.A.P. Intertrade Co., Ltd., Thailand) and SS Type 304 (AEC Industrial Services Co., Ltd., Thailand) coupons $(10 \times 20 \mathrm{~mm})$ were sanitized in $70 \%$ ethanol for $15 \mathrm{~min}$. Then, the coupons were autoclaved at $121^{\circ} \mathrm{C}$ for $15 \mathrm{~min}$ and were dried at $60^{\circ} \mathrm{C}$. For biofilm formation, the coupons were transferred to conical tubes containing TSB with approximately $6 \log$ CFU/ml of $S$. Typhimurium. The coupons were partly $\left(1 \mathrm{~cm}^{2}\right)$ submerged in the medium, and the remaining parts $\left(1 \mathrm{~cm}^{2}\right)$ were exposed to the air-liquid interphase to facilitate coupon removal using sterile forceps. The tubes were incubated at $37^{\circ} \mathrm{C}$ for $72 \mathrm{~h}$ to allow for biofilm formation.

\section{Biofilm Removal Effect}

After a 72-h incubation, the coupons were removed from the conical tubes using sterile forceps and then washed three times in phosphate-buffered saline (PBS; HiMedia) to remove loosely attached cells. The coupons were submerged in conical tubes individually containing $4 \mathrm{ml}$ of $2 \mathrm{x} \mathrm{MBC}$ of nutgall extract $(256 \mathrm{mg} / \mathrm{ml})+2 \mathrm{xMBC}$ of CTAB $(2.5 \mathrm{mg} / \mathrm{ml})$, nutgall extract alone $(256 \mathrm{mg} / \mathrm{ml})$, CTAB alone $(2.5 \mathrm{mg} / \mathrm{ml})$, distilled water, and $100 \mathrm{ppm}$ sodium hypochlorite ( $\mathrm{NaOCl}$; adjusted to $\mathrm{pH} 7$ using $0.1 \mathrm{~N} \mathrm{HCL})$ for 5,15 , and $30 \mathrm{~min}$. CTAB and $\mathrm{NaOCl}$ solutions were prepared by dissolving $\mathrm{CTAB}$ and $\mathrm{NaOCl}$ individually in sterile distilled water to obtain the target concentrations. The solution of nutgall extract in combination with CTAB (nutgall extract $+\mathrm{CTAB}$ ) was prepared by dissolving nutgall crude extract in CTAB solution to achieve the concentration of $256 \mathrm{mg} / \mathrm{ml}$ of nutgall extract $+2.5 \mathrm{mg} / \mathrm{ml}$ of CTAB. All sanitizing agents were stirred using a magnetic stirrer. The untreated control samples were included to determine sessile cell numbers of $S$. Typhimurium on coupons without sanitizing treatment.

Following sanitizing treatments, the coupons were removed from the conical tubes using sterile forceps and then washed three times in PBS to remove loosely attached cells or antimicrobial residues. Then, cotton swabs moistened with $0.1 \%$ peptone water (PW; HiMedia) were used to scrape the submerged parts $\left(1 \mathrm{~cm}^{2} \times 2\right.$ sides) of the coupons. The swabs were transferred to test tubes containing $10 \mathrm{ml}$ of $0.1 \% \mathrm{PW}$, followed by vortex agitation for $1 \mathrm{~min}$. The resulting samples were serially diluted in $9 \mathrm{ml}$ of $0.1 \% \mathrm{PW}$ and then spread on TSA plates. After a 24-h incubation at $37^{\circ} \mathrm{C}, \mathrm{S}$. Typhimurium colonies were enumerated. The limit of detection for plating enumeration was $1.70 \log \mathrm{CFU} / \mathrm{cm}^{2}$. The experiments were performed in triplicate; two independent samples were tested per replicate $(\mathrm{N}=6)$.

\section{Sample Preparation for SEM Analysis}

The PP and SS coupons containing biofilms were treated with sanitizing solutions for $30 \mathrm{~min}$. After that, the coupons were washed with PBS, followed by sterile distilled water. For sample fixation, the coupons were submerged in $4 \%$ glutaraldehyde for $2 \mathrm{~h}$ at $4^{\circ} \mathrm{C}$. After fixation, the coupons were washed with sterile distilled water and then subjected to a 15 -min gradual dehydration in $25 \%, 50 \%, 75 \%, 95 \%$, and $100 \%$ ethanol, respectively. After drying, the coupon samples were sputter-coated with PdAu and then subjected to SEM (Quanta 450, FEI, USA) observation.

\section{Statistical Analysis}

Populations of $S$. Typhimurium were logarithmically transformed and expressed as means \pm standard deviation. Logarithmically-transformed numbers of $S$. Typhimurium were analyzed by two-way analysis of variance (ANOVA) to determine differences $(p<0.05)$ in means, followed by mean separation using Tukey's Honestly Significant Differences (HSD) procedure. PASW Statistics software version 17.0.2 was utilized for statistical analysis.

\section{Results}

\section{Total Phenolic Content}

The total phenolic contents of ethanolic extract of Quercus infectoria gall was $625.82 \mathrm{mg}$ GAE/ g crude extract. The value was in line with the phenolic content (672.13 mg GAE/g extract) reported in the previous study [36].

\section{MICs and MBCs of Nutgall Extract and Surfactants}

The MIC and MBC of nutgall ethanolic extract against $S$. Typhimurium were $16 \mathrm{mg} / \mathrm{ml}$ and $128 \mathrm{mg} / \mathrm{ml}$, respectively. For the surfactants, the MIC and MBC values for CTAB against $S$. Typhimurium were $0.156 \mathrm{mg} / \mathrm{ml}$ and $1.25 \mathrm{mg} / \mathrm{ml}$, respectively, while the MIC and MBC values for SDS were $>100 \mathrm{mg} / \mathrm{ml}$.

Several studies have evaluated the antimicrobial effect of $Q$. infectoria gall against pathogenic microorganisms [22, 23, 25-27, 36]. Nanasombat et al. [36] reported that the MICs of Q. infectoria gall extract against Bacillus cereus, L. monocytogenes, Porphyromonas gingivalis, S. Typhimurium, and Y. enterocolitica were $0.32,>10,>10$, 
Table 1. Mean survivors $\left(\log \mathrm{CFU} / \mathrm{cm}^{2}\right)$ of $S$. Typhimurium sessile cells on polypropylene coupons after treatment with sanitizing agents.

\begin{tabular}{|c|c|c|c|}
\hline \multirow{3}{*}{ Treatment } & \multicolumn{3}{|c|}{ Mean survivors $\left(\log \mathrm{CFU} / \mathrm{cm}^{2}\right)$} \\
\hline & \multicolumn{3}{|c|}{ Sanitizer exposure time (min) } \\
\hline & $5 \mathrm{~min}$ & $15 \mathrm{~min}$ & $30 \mathrm{~min}$ \\
\hline Nutgall extract $(256 \mathrm{mg} / \mathrm{ml})$ & $3.54 \pm 0.02^{\mathrm{d}}$ & $3.14 \pm 0.03^{\mathrm{f}}$ & $2.51 \pm 0.07^{\mathrm{h}}$ \\
\hline Nutgall extract $(256 \mathrm{mg} / \mathrm{ml})+\mathrm{CTAB}(2.5 \mathrm{mg} / \mathrm{ml})$ & $3.29 \pm 0.03^{\mathrm{e}}$ & $2.84 \pm 0.06^{\mathrm{g}}$ & $2.14 \pm 0.12^{\mathrm{j}}$ \\
\hline CTAB $(2.5 \mathrm{mg} / \mathrm{ml})$ & $3.46 \pm 0.06^{\mathrm{d}}$ & $3.09 \pm 0.09^{\mathrm{f}}$ & $2.35 \pm 0.12^{\mathrm{i}}$ \\
\hline Water & $5.20 \pm 0.03^{\mathrm{b}}$ & $5.16 \pm 0.03^{b c}$ & $5.03 \pm 0.04^{c}$ \\
\hline $\mathrm{NaOCl}(100 \mathrm{ppm})$ & $3.31 \pm 0.03^{\mathrm{e}}$ & $2.94 \pm 0.09^{g}$ & $2.43 \pm 0.10^{\mathrm{hi}}$ \\
\hline Untreated control & $5.66 \pm 0.02^{\mathrm{a}}$ & $5.66 \pm 0.02^{\mathrm{a}}$ & $5.66 \pm 0.02^{\mathrm{a}}$ \\
\hline
\end{tabular}

Numbers across rows and columns not sharing the same letter are significantly different $(p<0.05)$.

The untreated control represents sessile cells on polypropylene coupons without sanitizing treatment.

$>10$, and $0.32 \mathrm{mg} / \mathrm{ml}$, respectively. Their MIC value against $S$. Typhimurium was in agreement with the MIC value $(16 \mathrm{mg} / \mathrm{ml})$ of nutgall extract from this study. Voravuthikunchai et al. [25] found that the MICs and MBCs of Q. infectoria ethanolic extract against $H$. pylori strains ranged from 3.12 to $6.25 \mathrm{mg} / \mathrm{ml}$ and 3.12 to $12.5 \mathrm{mg} / \mathrm{ml}$, respectively. Factors affecting MIC and MBC values can include the plant variety [37], the extraction method, and tested microorganisms [21]. In general, Gram-positive bacteria are more susceptible to the extract than Gramnegative bacteria due to the absence of a lipopolysaccharide (LPS) layer in the outer membrane that serves as an extra barrier to prevent access of bioactive molecules [21]. Although little is known about the mode of action of the nutgall extract, the previous study revealed that the nutgall extract could modify hydrophobic regions of microorganisms and may have partitioned the lipids of the bacterial membrane, resulting in more permeable membranes and, eventually, membrane leakage [26]. The proposed modes of action of the nutgall extract also include the ability to interfere with enzymes, including autolysins and B-lactamase [23].

In this study, cationic and anionic surfactants were utilized. The cationic surfactant CTAB is a quaternary ammonium compound widely used as a sanitizer and disinfectant for manual processing lines and surfaces in the food industry [38]. SDS is an anionic surfactant generally employed for many cleaning applications and is also highly effective in removing oily stains and residues [39]. CTAB [38, 40] and SDS [35, 39] have been reported to exhibit antimicrobial activities. CTAB could form an electrostatic bond with negatively charged sites on microbial cell walls, leading to stress in the cell wall, cell lysis, and death [40]. It has also been reported that CTAB could induce superoxide stress in microbial cells [38]. SDS has been shown to denature membrane-located proteins and damage microbial cell membranes, resulting in leakage of the cytoplasmic constituents and potentially depolarization of the membrane [35]. In the present study, CTAB was more effective in inhibiting and inactivating planktonic cells of $S$. Typhimurium than SDS; this could be due to the positive charge of CTAB that caused electrostatic attraction with the microbial membranes [35]. Therefore, CTAB was selected to use in combination with nutgall extract for removing $S$. Typhimurium biofilms from PP and SS coupons.

Biofilm Removal Effect of Sanitizers against Preformed Biofilm on Polypropylene and Stainless Steel Coupons

Tables 1 and 2 present the mean survivors $\left(\log \mathrm{CFU} / \mathrm{cm}^{2}\right)$ of $S$. Typhimurium sessile cells on PP and SS coupons after treatment with sanitizing agents for 5,15 , and $30 \mathrm{~min}$, respectively. The numbers of sessile cells obtained from untreated PP and SS control samples were $5.66 \pm 0.02$ and $5.97 \pm 0.01 \log \mathrm{CFU} / \mathrm{cm}^{2}$, respectively. The greatest biofilm removal efficacy was observed with nutgall $+\mathrm{CTAB}$ at 30 -min exposure time; the remaining sessile cells embedded in biofilm on PP and SS coupons were $2.14 \pm 0.12 \log \mathrm{CFU} / \mathrm{cm}^{2}$ and $2.20 \pm 0.17 \mathrm{log} \mathrm{CFU} / \mathrm{cm}^{2}$, respectively. Water treatment resulted in a statistical reduction of sessile cells on PP $\left(0.46\right.$ to $0.63 \mathrm{log} \mathrm{CFU} / \mathrm{cm}^{2}$ reduction) and $\mathrm{SS}$ ( 0.73 to $0.87 \log \mathrm{CFU} / \mathrm{cm}^{2}$ reduction) coupons, suggesting that water may have exerted a rinsing effect on biofilm cells.

Table 2. Mean survivors $\left(\log \mathrm{CFU} / \mathrm{cm}^{2}\right)$ of $S$. Typhimurium sessile cells on stainless steel coupons after treatment with sanitizing agents.

\begin{tabular}{|c|c|c|c|}
\hline \multirow{3}{*}{ Treatment } & \multicolumn{3}{|c|}{ Mean survivors $\left(\log \mathrm{CFU} / \mathrm{cm}^{2}\right)$} \\
\hline & \multicolumn{3}{|c|}{ Sanitizer exposure time (min) } \\
\hline & $5 \mathrm{~min}$ & $15 \mathrm{~min}$ & $30 \mathrm{~min}$ \\
\hline Nutgall extract $(256 \mathrm{mg} / \mathrm{ml})$ & $3.53 \pm 0.02^{\mathrm{d}}$ & $2.92 \pm 0.08^{g}$ & $2.61 \pm 0.06^{\mathrm{h}}$ \\
\hline Nutgall extract $(256 \mathrm{mg} / \mathrm{ml})+$ CTAB $(2.5 \mathrm{mg} / \mathrm{ml})$ & $3.18 \pm 0.05^{\mathrm{f}}$ & $2.84 \pm 0.10^{\mathrm{g}}$ & $2.20 \pm 0.17^{\mathrm{j}}$ \\
\hline CTAB $(2.5 \mathrm{mg} / \mathrm{ml})$ & $3.57 \pm 0.02^{\mathrm{d}}$ & $3.17 \pm 0.04^{\mathrm{f}}$ & $2.47 \pm 0.11^{\mathrm{i}}$ \\
\hline Water & $5.24 \pm 0.02^{\mathrm{b}}$ & $5.20 \pm 0.02^{\mathrm{bc}}$ & $5.10 \pm 0.02^{c}$ \\
\hline $\mathrm{NaOCl}(100$ ppm) & $3.38 \pm 0.04^{\mathrm{e}}$ & $3.10 \pm 0.07^{\mathrm{f}}$ & $2.60 \pm 0.07^{\mathrm{hi}}$ \\
\hline Untreated control & $5.97 \pm 0.01^{\mathrm{a}}$ & $5.97 \pm 0.01^{\mathrm{a}}$ & $5.97 \pm 0.01^{\mathrm{a}}$ \\
\hline
\end{tabular}

Numbers across rows and columns not sharing the same letter are significantly different $(p<0.05)$.

The untreated control represents sessile cells on stainless steel coupons without sanitizing treatment. 
PP and SS are food contact surface materials commonly used in the food industry and household [41]. In this study, the effects of nutgall extract + CTAB for removing $S$. Typhimurium biofilms from PP and SS coupons were evaluated in comparison with nutgall extract alone, $\mathrm{CTAB}$, water, $\mathrm{NaOCl}$, and untreated control samples. Overall, the biofilm removal effects of sanitizers against $S$. Typhimurium biofilms on PP and SS coupons followed the trend from greatest to least of nutgall extract $+\mathrm{CTAB} \geq \mathrm{NaOCl} \geq \mathrm{CTAB} \geq$ nutgall extract alone $>$ water. The biofilm removal efficacy of sanitizers seemed to increase with the exposure time. $\mathrm{NaOCl}$ is an oxidizing agent widely used for sanitizing food contact surfaces in food processing plants [42]. In the present study, $\mathrm{NaOCl}$ was unable to completely remove the biofilms of $S$. Typhimurium at all exposure times. Previous studies also showed that $\mathrm{NaOCl}$ failed to completely eradicate microbial biofilms from food contact surfaces [14, 42, 43]. de Souza et al. [42] cultivated S. aureus biofilms on PP and SS coupons in a meat-based broth at 7 and $28^{\circ} \mathrm{C}$. After a $30 \mathrm{~s}$-exposure to $\mathrm{NaOCl}(250 \mathrm{mg} / \mathrm{l})$, S. aureus sessile cells on PP and SS coupons reduced to 1.9-2.4 log CFU/ $\mathrm{cm}^{2}$ and 2.6-2.7 $\log \mathrm{CFU} / \mathrm{cm}^{2}$, respectively. Corcoran et al. [14] reported that 48 -h and 168 -h S. enterica biofilms treated with $500 \mathrm{mg} / \mathrm{l}$ of $\mathrm{NaOCl}(10,45$, and 90-min exposure time) resulted in 0.13-1.1 log CFU/coupon reduction and 0.22$0.97 \log \mathrm{CFU} /$ coupon reduction, respectively; a greater reduction of biofilms was observed as the exposure time increased [14]. For CTAB, Wang et al. [44] found that $1 \mathrm{mg} / \mathrm{ml}$ and $10 \mathrm{mg} / \mathrm{ml}$ of CTAB could remove $100 \%$ of cells (approximately $5.39 \log \mathrm{CFU} / \mathrm{cm}^{2}$ ) of Salmonella biofilms at the irreversible attachment phase from SS surfaces. However, Simões et al. [40] demonstrated that the application of CTAB singly did not promote detachments of Pseudomonas fluorescens biofilms formed on SS slides under turbulent and laminar flow conditions. In this study, nutgall extract $+\mathrm{CTAB}$ exhibited the greatest biofilm removal efficacy. This could have been due to the ability of $\mathrm{CTAB}$ to disrupt hydrophobic interactions associated with the crosslinking of the biofilm matrix [40], allowing nutgall extract to penetrate the biofilm EPS matrix more efficiently. It is worth noting that this study focuses on the removal of preformed biofilm on food contact surfaces. While evaluation of biofilm formation in the presence of sanitizing agents was not completed in this study, previous work has reported that higher sanitizer concentrations are required to remove preformed biofilms of $S$. Typhimurium than to inhibit biofilm formation on food contact surfaces [32]. To the authors' knowledge, there has been no research on the biofilm removal effect of nutgall extract in combination with a surfactant. Previous research has demonstrated inhibition of Streptococcus mutans biofilm formation in the presence of nutgall extract but did not report the removal of preformed biofilm in the study [24]. It should also be noted that the authors' study employed the immersion method without additional physical treatment for removing Salmonella biofilm from PP and SS coupons. Applying additional physical treatment before or after exposure to nutgall extract $+\mathrm{CTAB}$ may therefore have resulted in increased biofilm removal efficacy and a lower concentration of nutgall extract + CTAB required for biofilm removal. In the food processing plants, the commonly used chemical agents can cause antimicrobial resistance in targeted microorganisms [29-32]. Therefore, nutgall extract + CTAB could potentially be utilized as an alternative sanitizer for removing biofilms from food contact surfaces to prevent microbial resistance in food processing plants and households.
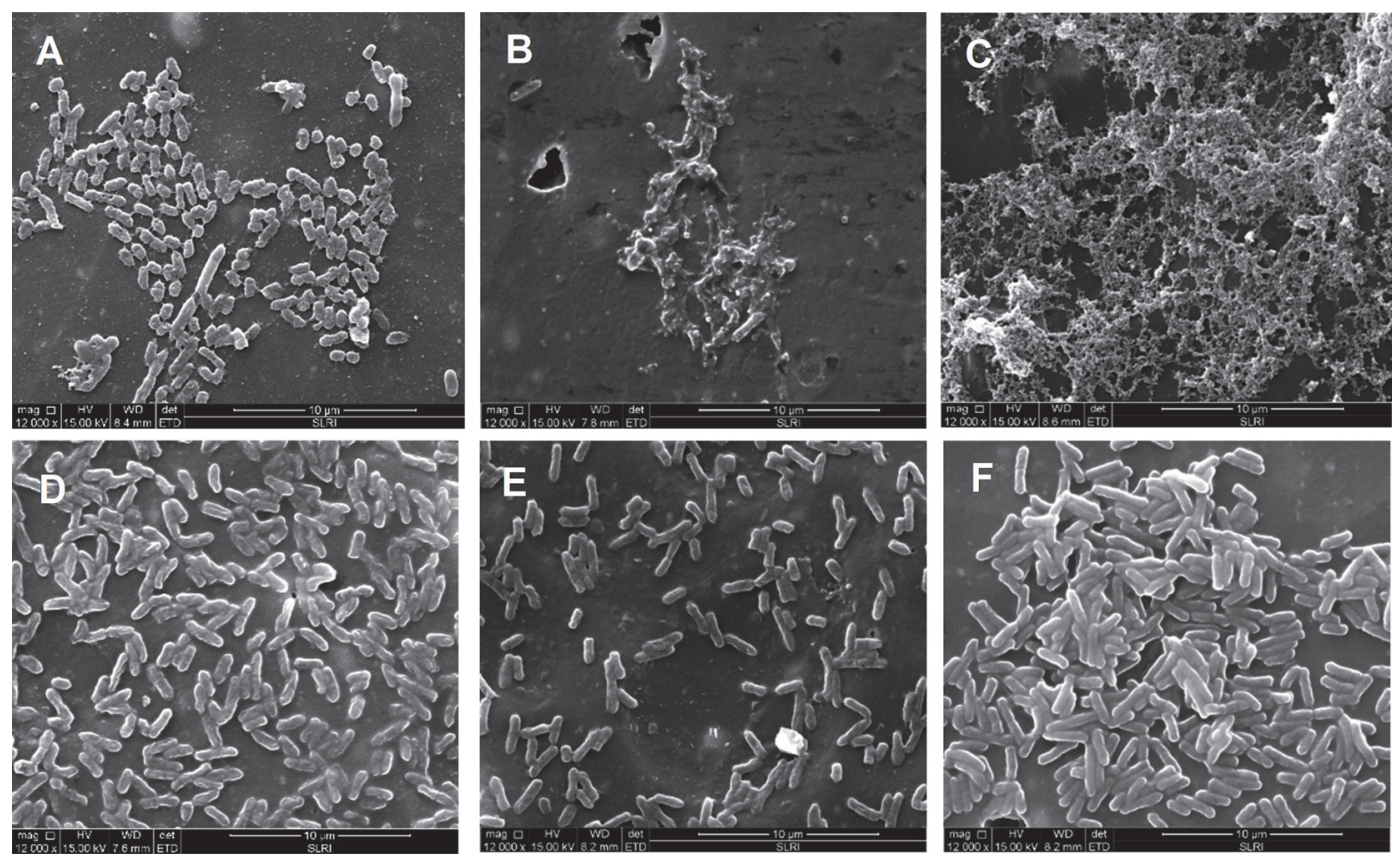

Fig. 1. SEM images of S. Typhimurium on polypropylene coupons after treatment with sanitizing agents for 30 min. (A) Nutgall extract; (B) nutgall extract + CTAB; (C) CTAB; (D) water; (E) NaOCl; (F) untreated control. The untreated control sample did not receive sanitizing treatment. 

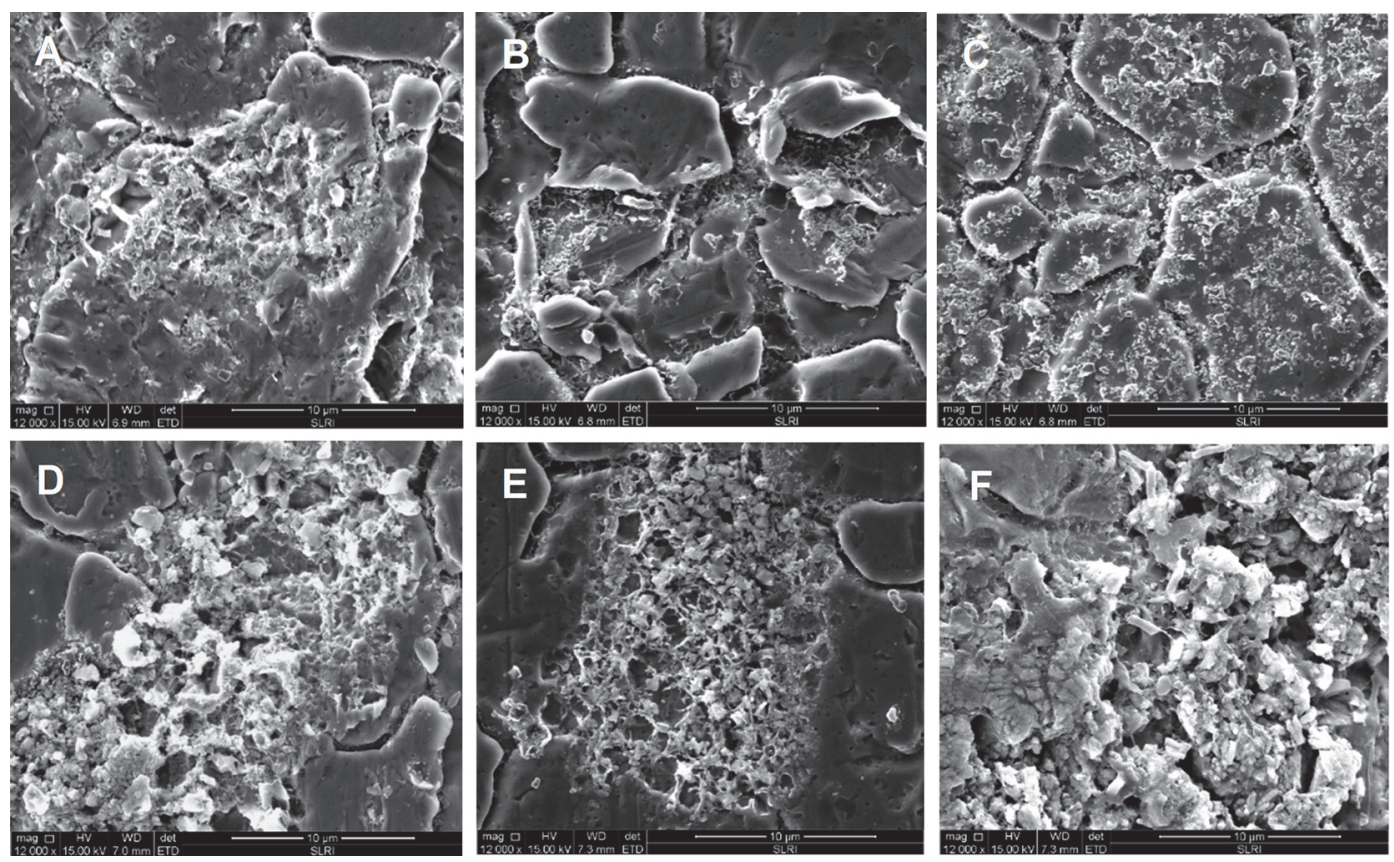

Fig. 2. SEM images of $S$. Typhimurium on stainless steel coupons after treatment with sanitizing agents for 30 min. (A) Nutgall extract; (B) nutgall extract + CTAB; (C) CTAB; (D) water; (E) NaOCl; (F) untreated control. The untreated control sample did not receive sanitizing treatment.

\section{SEM Analysis}

The morphology of $S$. Typhimurium biofilms on PP and SS coupons observed under SEM are shown in Figs. 1 and 2, respectively. The untreated control sample on the PP coupon (Fig. 1F) and the sample treated with distilled water (Fig. 1D) exhibited intact biofilm structures with rod-shaped sessile cells. In accordance with the plate count results (Tables 1 and 2), a reduction of sessile cells of S. Typhimurium biofilms on PP and SS coupons occurred after treatment with sanitizers. Not all sanitizer treatments resulted in complete removal of $S$. Typimurium biofilms on PP and SS coupons since remaining sessile cells were observed after the treatments. However, the greatest reduction of $S$. Typhimurium sessile cells was observed with the samples treated with nutgall extract + CTAB (Figs. 1B and 2B). A reduction of sessile cells was also observed with samples treated with water (Figs. 1D and 2D), suggesting that water may have displayed a rinsing effect. Treatment with nutgall extract on PP (Fig. 1A) resulted in shrinkage of sessile cells. Biofilm on PP coupons treated with CTAB + nutgall (Fig. 1B) and CTAB (Fig. 1C) showed morphological alterations with wrinkles and ruptures, suggesting that CTAB + nutgall and CTAB alone may have disrupted the cell wall of the sessile cells. The untreated control sample on an SS coupon (Fig. 2F) showed an intact biofilm morphology with dense extracellular polymeric substances (EPS). Excepting exposure to water, biofilm exhibited ruptured EPS after exposure to nutgall extract (Fig. 2A), nutgall extract + CTAB (Fig. 2B), CTAB (Fig. 2C), and $\mathrm{NaOCl}$ (Fig. 2E). Previous studies also showed that the application of $\mathrm{NaOCl}$ or $\mathrm{CTAB}$ to preformed microbial biofilms on food contact surfaces caused morphological changes of biofilm sessile cells but did not result in complete removal of microbial biofilms. Residual cells after sanitizer exposure still remained on the tested surfaces $[40,42,43]$. SEM analysis of microbial biofilms after treatment with plant-derived antimicrobials has been reported in several studies [45-47]. Amaral et al. [45] demonstrated that treatment with carvacrol and thymol resulted in a disruption of the typical structure of biofilms and diffuse adherence of Salmonella spp. biofilms on polypropylene surfaces. Guo et al. [46] showed that exposure to essential oil from Citrus Changshan-huyou Y.B. Chang revealed the extensive disruption and architectural changes of L. monocytogenes biofilms. Rodrigues et al. [47] reported that exposure to oregano and carvacrol essential oil caused morphological alterations with bubbles or spot formations and changes in fimbriae-like filamentous structures on the surfaces of mature S. aureus biofilms.

\section{Conclusions}

In this study, overall, the biofilm removal efficacy of the tested sanitizing agents against $S$. Typhimurium biofilms on PP and SS surfaces followed the trend of nutgall extract $+\mathrm{CTAB} \geq \mathrm{NaOCl} \geq \mathrm{CTAB} \geq$ nutgall extract alone $>$ water. The biofilm removal efficacy of the sanitizers seemed to increase with the exposure time. The SEM analysis revealed that $S$. Typhimurium biofilms on PP and SS surfaces after a 30-min exposure to nutgall extract + $\mathrm{CTAB}$ exhibited morphological alterations with wrinkles and ruptures. This study indicates that nutgall extract + $\mathrm{CTAB}$ may be an alternative to frequently used sanitizers for removing biofilms from food contact surfaces in food processing environments and households. 


\section{Acknowledgments}

This research was supported by the Faculty of Science, King Monkut's University of Technology Thonburi Grant No. SCI60-001 and the KMUTT Research Fund. The authors would like to acknowledge Mr.Picha Panmongkol from AEC Industrial Services Co., Ltd. for the kind provision of stainless steel coupons. Also, the authors would like to thank Dr. Sirirat Wachiralurpan from the ISTRS, KMUTT, for assistance with sample preparation for SEM analysis.

\section{Conflict of Interest}

The authors have no financial conflicts of interest to declare.

\section{References}

1. World Health Organization (WHO). 2015. WHO estimates of the global burden of foodborne diseases. Available from https:// apps.who.int/iris/bitstream/handle/10665/199350/9789241565165_eng.pdf?sequence=1. Accessed Oct. 8, 2020.

2. World Health Organization (WHO). 2018. Salmonella (non-typhoidal). Available from https://www.who.int/news-room/factsheets/detail/salmonella-(non-typhoidal). Accessed July 21, 2020.

3. Center for Disease Control and Prevention (CDC). 2020. Salmonella. Available from https://www.cdc.gov/salmonella/. Accessed July 21, 2020

4. European Food Safety Authority (EFSA). 2018. The European Union summary report on trends and sources of zoonoses, zoonotic agents and food-borne outbreaks in 2017. EFSA J. 16: e05500-e05500.

5. Department of Disease Control (DDC). 2019. Food Poisoning. Available from https://www.boe.moph.go.th/boedb/surdata/506wk/ y62/d03_5262.pdf. Accessed. July 21, 2020

6. Scanlan CM. 2004. Genus Salmonella, pp. 116-119. Bacterial diseases of domestic animals. 2nd Ed. Brown Paw Educational Media, College Station, Texas. USA.

7. Chmielewski RAN, Frank JF. 2003. Biofilm formation and control in food processing facilities. Compr. Rev. Food Sci. Food Saf. 2: 22-32.

8. Jun W, Kim MS, Cho BK, Millner PD, Chao KL, Chan DE. 2010. Microbial biofilm detection on food contact surfaces by macro-scale fluorescence imaging. J. Food Eng. 99: 314-322.

9. Srey S, Jahid IK, Ha S-D. 2013. Biofilm formation in food industries: A food safety concern. Food Control 31: 572-585.

10. LeChevallier MW, Cawthon CD, Lee RG. 1988. Inactivation of biofilm bacteria. Appl. Environ. Microbiol. 54: 2492-2499.

11. Kumar CG, Anand SK. 1998. Significance of microbial biofilms in food industry: a review. Int. J. Food Microbiol. 42: 9-27.

12. Simões M, Simões LC, Vieira MJ. 2010. A review of current and emergent biofilm control strategies. LWT-Food Sci. Technol. 43: 573-583.

13. Van Houdt R, Michiels CW. 2010. Biofilm formation and the food industry, a focus on the bacterial outer surface. J. Appl. Microbiol. 109: $1117-1131$.

14. Corcoran M, Morris D, De Lappe N, O'Connor J, Lalor P, Dockery P, et al. 2014. Commonly used disinfectants fail to eradicate Salmonella enterica biofilms from food contact surface materials. Appl. Environ. Microbiol. 80: 1507-1514.

15. Cogan TA, Bloomfield SF, Humphrey TJ. 1999. The effectiveness of hygiene procedures for prevention of cross-contamination from chicken carcasses in the domestic kitchen. Lett. Appl. Microbiol. 29: 354-358.

16. Schlegelova J, Babak V, Holasova M, Konstantinova L, Necidova L, Sisak F, et al. 2010. Microbial contamination after sanitation of food contact surfaces in dairy and meat processing plants. Czech J. Food Sci. 28: 450-461.

17. Djordjevic D, Wiedmann M, McLandsborough LA. 2002. Microtiter plate assay for assessment of Listeria monocytogenes biofilm formation. Appl. Environ. Microbiol. 68: 2950-2958.

18. Hapidin H, Rozelan D, Abdullah H, Wan Hanaffi WN, Soelaiman IN. 2015. Quercus infectoria gall extract enhanced the proliferation and activity of human fetal osteoblast cell line (hFOB 1.19). Malays. J. Med. Sci. 22: 12-22.

19. Baharuddin NS, Abdullah H, Abdul Wahab WNAW. 2015. Anti-Candida activity of Quercus infectoria gall extracts against Candida species. J. Pharm. Bioallied Sci. 7: 15-20.

20. Voravuthikunchai S, Chusri S, Suwalak S. 2008. Quercus infectoria. Oliv. Pharm. Biol. 46: 367-372.

21. Satirapathkul C, Leela T. 2011. Growth inhibition of pathogenic bacteria by extract of Quercus Infectoria galls. Int. J. Biosci. Biochem. Bioinformatics 1: 26-31.

22. Chusri S, Voravuthikunchai SP. 2009. Detailed studies on Quercus infectoria Olivier (nutgalls) as an alternative treatment for methicillin-resistant Staphylococcus aureus infections. J. Appl. Microbiol. 106: 89-96.

23. Chusri S, Voravuthikunchai SP. 2011. Damage of staphylococcal cytoplasmic membrane by Quercus infectoria G. Olivier and its components. Lett. Appl. Microbiol. 52: 565-572.

24. Mohammadi-Sichani M, Karbasizadeh V, Dokhaharani SC. 2016. Evaluation of biofilm removal activity of Quercus infectoria galls against Streptococcus mutans. Dent. Res. J. 13: 46-51.

25. Voravuthikunchai S, Limsuwan S, Mitchell H. 2006. Effects of Punica granatum pericarps and Quercus infectoria nutgalls on cell surface hydrophobicity and cell survival of Helicobacter pylori. J. Health Sci. 52: 154-159.

26. Voravuthikunchai S, Suwalak S. 2009. Changes in cell surface properties of shiga toxigenic Escherichia coli by Quercus infectoria G. Olivier. J. Food Prot. 72: 1699-1704.

27. Chusri S, Phatthalung PN, Voravuthikunchai SP. 2012. Anti-biofilm activity of Quercus infectoria G. Olivier against methicillinresistant Staphylococcus aureus. Lett. Appl. Microbiol. 54: 511-517.

28. Wan Nor Amilah WA, Masrah M, Hasmah A, Noor Izani NJ. 2014. In vitro antibacterial activity of Quercus infectoria gall extracts against multidrug resistant bacteria. Trop. Biomed. 31: 680-688.

29. Falcó I, Verdeguer M, Aznar R, Sánchez G, Randazzo W. 2018. Sanitizing food contact surfaces by the use of essential oils. Innov. Food Sci. Emerg. 51: 220-228.

30. Halden RU. 2014. On the need and speed of regulating triclosan and triclocarban in the United States. Environ. Sci. Technol. 48: $3603-3611$.

31. Xue R, Shi H, Ma Y, Yang J, Hua B, Inniss EC, et al. 2017. Evaluation of thirteen haloacetic acids and ten trihalomethanes formation by peracetic acid and chlorine drinking water disinfection. Chemosphere 189: 349-356.

32. Soni KA, Oladunjoye A, Nannapaneni R, Schilling MW, Silva JL, Mikel B, et al. 2013. Inhibition and inactivation of Salmonella Typhimurium biofilms from polystyrene and stainless steel surfaces by essential oils and phenolic constituent carvacrol. J. Food Prot. 76: 205-212.

33. Dewanto V, Wu X, Adom KK, Liu RH. 2002. Thermal processing enhances the nutritional value of tomatoes by increasing total antioxidant activity. J. Agric. Food Chem. 50: 3010-3014.

34. Bazargani MM, Rohloff J. 2016. Antibiofilm activity of essential oils and plant extracts against Staphylococcus aureus and Escherichia coli biofilms. Food Control 61: 156-164. 
35. Ruengvisesh S, Loquercio A, Castell-Perez E, Taylor TM. 2015. Inhibition of bacterial pathogens in medium and on spinach leaf surfaces using plant-derived antimicrobials loaded in surfactant micelles. J. Food Sci. 80: M2522-2529.

36. Nanasombat S, Kuncharoen N, Ritcharoon B, Sukcharoen P. 2018. Antibacterial activity of thai medicinal plant extracts against oral and gastrointestinal pathogenic bacteria and prebiotic effect on the growth of lactobacillus acidophilus. Chiang Mai J. Sci. 45: 33-44.

37. Haque ASA, Ahmad W, Khan RM, Hasan A. 2016. Ethnopharmacology of Quercus infectoria galls: a review. Hippocratic J. Unani Med. 11: 105-118.

38. Nakata K, Tsuchido T, Matsumura Y. 2011. Antimicrobial cationic surfactant, cetyltrimethylammonium bromide, induces superoxide stress in Escherichia coli cells. J. Appl. Microbiol. 110: 568-579.

39. Bhattarai A, Niraula T, Chatterjee S. 2014. Sodium dodecyl sulphate: A very useful surfactant for scientific investigations. J. Knowledge Innov. 2: 111-113.

40. Simões M, Pereira MO, Vieira MJ. 2005. Action of a cationic surfactant on the activity and removal of bacterial biofilms formed under different flow regimes. Water Res. 39: 478-486.

41. Vidacs A, Kerekes E, Rajko R, Petkovits T, Alharbi NS, Khaled JM, et al. 2018. Optimization of essential oil-based natural disinfectants against Listeria monocytogenes and Escherichia coli biofilms formed on polypropylene surfaces. J. Mol. Liq. 255: 257-262.

42. de Souza EL, Meira QGS, de Medeiros Barbosa I, Athayde AJAA, da Conceicão ML, de Siqueira Júnior JP. 2014. Biofilm formation by Staphylococcus aureus from food contact surfaces in a meat-based broth and sensitivity to sanitizers. Braz. J. Microbiol. 45: 67-75.

43. da Silva Meira QG, de Medeiros Barbosa I, Alves Aguiar Athayde AJ, de Siqueira-Júnior JP, de Souza EL. 2012. Influence of temperature and surface kind on biofilm formation by Staphylococcus aureus from food-contact surfaces and sensitivity to sanitizers. Food Control 25: 469-475.

44. Wang H, Wang H, Xing T, Wu N, Xu X, Zhou G. 2016. Removal of Salmonella biofilm formed under meat processing environment by surfactant in combination with bio-enzyme. LWT - Food Sci. Technol. 66: 298-304.

45. Amaral VCS, Santos PR, da Silva AF, dos Santos AR, Machinski Jr M, Mikcha JMG. 2015. Effect of carvacrol and thymol on Salmonella spp. biofilms on polypropylene. Int. J. Food Sci. Technol. 50: 2639-2643.

46. Guo J, Gao Z, Li G, Fu F, Liang Z, Zhu H, et al. 2019. Antimicrobial and antibiofilm efficacy and mechanism of essential oil from Citrus Changshan-huyou Y. B. chang against Listeria monocytogenes. Food Control 105: 256-264.

47. Rodrigues JBD, de Souza NT, Scarano JOA, de Sousa JM, Lira MC, de Figueiredo R, et al. 2018. Efficacy of using oregano essential oil and carvacrol to remove young and mature Staphylococcus aureus biofilms on food-contact surfaces of stainless steel. Lwt-Food Sci. Technol. 93: 293-299. 